\title{
Covert bacteriuria in schoolchildren
}

\author{
Taralan Tambunan, ${ }^{1}$ Yuli Kumalawati, ${ }^{2}$ Partini P Trihono,, ${ }^{1}$ Astuti Giantini, ${ }^{2}$ \\ Muzal Kadim, ${ }^{1}$ Vera Irawani ${ }^{3}$
}

'Dept. of Child Health, ${ }^{2}$ Clinical Pathology, ${ }^{3}$ Undergraduate Medical Student, Faculty of Medicine University of Indonesia, Jakarta

\begin{abstract}
Covert bacteriuria is defined as significant bacteriuria detected during a screening program. This study was done as a part of pilot program held by Medical School University of Indonesia namely Community Health Program. The screening was carried out at four Primary School at Cibubur Subdistrict Eastern Jakarta. The population target was focussed on children at the third, fourth and fifth grade from each school. Screening urinalyses include examination for the presence of glucose, protein, blood and bacteria. There were 460 children enrolled to this study, but only 449 cases were eligible for assessment comprising 217 males and 232 females aged ranged between 7.4-14.1 years. Covert bacteriuria were found in ten cases $(2.22 \%)$, comprising five males and females consecutively. Antibiotics were not given. Repeated urine culture done two weeks later revealed that six cases cured spontaneously, four other cases still showing bacteriuria although all cases remain asymptomatic. We conclude that covert bacteriuria in schoolchildren is a benign condition, most of them are spontaneously cured without antibiotic treatment. This conclusion is in accordance with the opinion of most authors that screening for bacteriuria in healthy children does not have a place in any age group including schoolchildren. [Paediatr Indones $2001 ; 41: 38-41]$
\end{abstract}

Keywords: covert bacteriuria, screening, schoolchildren

COVERT BACTERIURIA IS DEFINED AS SIGNIFICANT bacteriuria detected during a screening program. ${ }^{1}$ This was formerly known as asymptomatic bacteriuria (ABU), but since many of those cases found to have bacteriuria during screening program had symptoms referable to lower urinary tract, covert bacteriuria is therefore preferred as an appropriate term. During the era of 1960 s to 1980 s many studies concerning screening surveys for asymptomatic bacteriuria in schoolchildren were published. ${ }^{1.6}$ During that period the screening was promoted on the premise that early detection and treatment of asymptomatic bacteriuria can prevent pyelonephritis, renal scarring and eventually end-stage renal disease. However, ten years later the rightness of this premise was considered to be doubtful by some experts. Kemper et al, for instance,

Correspondence: Taralan Tambunan, MD, Department of Child Health, Medical School, University of Indonesia, Jalan Salemba 6, Jakarta, Indonesia. Tel. 62-21-3907742; Fax. 3907743 reviewed published studies to answer the question wether early detection of covert bacteriuria reduce the risk of pyelonephritis and renal scarring, and also about the cost of screening test in terms of false positive and false negative results and dollars charged. ${ }^{7}$ Their conclusion is that there is no evidence that detection and treatment of children with covert bacteriuria prevents subsequent pyelonephritis and renal scarring, and it is no longer considered to screen healthy children for bacteriuria. Although such screening program had been conducted broadly by many authors, the same study has never been reported in Indonesian literature.

This study was done as a part of a pilot program held by Faculty of Medicine University of Indonesia namely "Program Menyehatkan Bangsa" (Community Health Programme). One of the activity of this program was a screening survey for health status of schoolchildren at East Jakarta included physical condition, nutritional status, peripheral blood pictures, parasitic 
infestation and urinalyses (protein, glucose, blood and bacteria) as baseline data for planning the proper management in enhancing the health status of these schoolchildren.

\section{Methods}

The screening was carried out at four primary schools at Cibubur Subdistrict, Eastern Jakarta in August 1999. Three out of the schools were governmental schools (SD Pekayon I, Il and 18) and one private school (SD Yasmin). The target population was focussed on children at the third, fourth and fifth grades from each school. The screening was carried out at the school using a mobile clinic laboratory in a period of five consecutive days. Informed consent was requested from the parents prior to the study. A routine examination was carried out; this include measurement of height, weight and blood pressure. Screening urinalyses include examinations for the presence of glucose, protein, blood and bacteria by the team from Clinical Pathology and Microbiology Departments. Abnormal urinary findings were defined according to these definitions: proteinuria, $>30 \mathrm{mg} / \mathrm{dl}$ (determined by the semiquantitative dipstick test (Multisistix SG, Bayer) and confirmed by conventional acid turbidity test); and hematuria, number of sediment urinary red blood cells $>5 /$ high-power field by microscopic examination. A midstream specimen of urine was collected in the school area using a sterile container for microbiologic investigation. The specimen was inoculated onto both blood agar and a MacConkey agar plates. Urine culture was only conducted once to each child. Significant bacteriuria was defined as a colony count of greater than 100.000/ $\mu 1$ urine of microorganism obtained on clean voided culture. Repeated urine culture was done to all cases showing significant bacteriuria on the first examination.

\section{Results}

There were 460 children enrolled to this study but eleven out of them were omitted due to inadequacy of clinical data, or improper technique for urine collection, or the informed consent were not available. The remaining 449 children were eligible for assessment, consisted of 217 males and 232 females, age range between $7.4 \cdot 14.1$ years (mean 9.35; SD 1.2). The clinical condition of all children was good, blood pressures were all in normal limits for age. Slight proteinuria (dipstick +1 ), was detected in 31 children (7.1\%). Microscopic hematuria was detected in three cases. Significant bacteriuria were found in ten cases $(2,2 \%)$, comprising 5 males and 5 females, aged ranged between $8-10$ years. Antibiotics were not administered to any of these cases. Further analyses were focussed on these group of children. Baseline data and the results of urine cultures were shown in table. There were four children (cases no. 3, 6, 7, and 10) categorized as undernourished with the body weight of less than fifth percentile according to NCHS, one with obesity (case no. 1) and the rest five children were in good nutritional status. Blood pressures were all in normal range for their age. Urinalyses were normal in 8 cases, proteinuria and pyuria were detected in one case (case no 1 ). The result of the first urine culture showed various species of microorganisms included E. coli, Proteus Sp, Pseudomonas, Staphylococci and Streptococci. Repeated urine culture done two weeks after the first investigation revealed that four cases still showed significant bacteriuria, while the remaining six cases gave negative result. Again, antibiotics were not given to those cases with significant bacteriuria. Case no. 1 were judged as having symptomatic lower urinary infection due to the presence of dysuria, pyuria, proteinuria associated with an abundant amount of microorganism isolated on urine culture. Repeated urine culture done two weeks later still showed the same strain of microorganisms but further follow-up against this case revealed that the symptoms of lower urinary infection was subsided spontaneously without any antimicrobial treatment. Urinalyses revealed a normal picture, no proteinuria nor pyuria, and ultrasonography showed a normal urinary tract imaging.

\section{Discussion}

Urinary tract infection (UTI) constitutes an important medical problem for several reasons. The wide range of clinical patterns of UTI includes acute symptomatic infection involved the kidney, which poses a threat to the renal parenchyma and its function. $\mathrm{ABU}$ is at the other and of the spectrum; patients with covert bacteriuria have few or no symptoms of UTI, and bacteria is generally discovered only on routine examination. As a part of a pilot program, this study 
was focussed mainly on the profile of covert bacteriuria detected during this screcning program. Even though our sample size was relatively small compared to such screening conducted by several authors, ${ }^{1.4}$ the overall prevalence of covert bacteriuria in this study (2.22\%) is not much difference in compare to the result of New Castle asymptomatic bacteriuria research group in 1975 who found the prevalence of $1,9 \% .4 \quad$ The prevalence rate of covert bacteriuria in boys in our study is about $2,3 \%$ while in girls $2,16 \%$. This finding is quite different in compare to many studies reported that the prevalence of covert bacteriutia is consistently higher in schoolgirls. Kunin et al for instance reported that only 2 cases were detected among the 7731 malcs surveyed in the various studies, on overall prevalence of only 0,026\%.2 New Castle research group (1975) reported that prevalence of $\mathrm{ABU}$ in girls aged 7 to 11 years was 2,5\% whilc in boys aged 5 to 18 years was very low $(0,2 \%) .4$ There is no definite explanation why is the prevalence of $\mathrm{ABU}$ in boys in our study so high and even higher than girls. To proof this discrepancy, two consecutive urine culture may give a more accurate prevalence of $\mathrm{ABU}$ in this study but this procedure can not be donc due to the constraint of budgct allocation. Of the ten children with covert bacteriuria, nine were rcgarded as having asymptomatic bacteriuria since none of them presenting clinical symptom related to urinary tract infection. Urinalyses werc normal in eight cases. Only one case (case no. 10) presenting an abnormal urinalyses i.e. microhematuria. The presence of hematuria in rclation to urinary tract infection usually derived from acute cystitis, though usually this is microscopic rather than overt macroscopic hematuria. ${ }^{8}$ The presence of various strains of microorganism detccted on urine cultures in this study reflected that the source of bacteria entered the urinary tract not only from gastrointestinal tract, vaginal or pcriurethral site, but also from skin or upper respiratory tract as stated by Mcrit (1980), that the child with an upper respiratory tract infection (rhinitis, pharyngitis, etc.) can spread the flora from the oropharynx to the genital tract.' It is interesting to note that without any antibiotic trcatment, six cases showed spontaneous cured, four other cases still have bacteriuria, three out of them showed changing strain of bactcria, while the rest one case showed persistent bacteriuria (case no. 1). This case formcrly regarded as having symptomatic lower urinary tract infection, but on further follow up the symptoms of lower urinary infection was subsided spontaneously without antibiotic treatment. The idca of withholding the antibiotic treatment of $\mathrm{ABU}$ in schoolchildren has been proposed by some authors since 30 years ago. Non treatment of $\mathrm{ABU}$ in schoolchildren especially in girls was tested in a number of prospective studics during the $1970 \mathrm{~s} .{ }^{10}$ The non-treatment was showing to be associated with normal growth of the kidncy without development of new scars, provided that the urinary tract was radiologically normal. Thus the presence of $\mathrm{ABU}$ had no impact on renal growth. Based on this finding, the concept of covert bacteriuria as a risk to the kidney has becn revised, however and there was no evidence to suggest that antibacterial treatment of schoolchildren with covert bacteriuria had a beneficial effect. ${ }^{10}$ Elimination of bacteria in asymptomatic children resulted in recurrence in $80 \%$ of cases. Antibiotic therapy has the potential to alter normal bacterial flora and increase colonization of uropathogens and might anticipate problems for treating $A B U .{ }^{12}$ Hencc, most authors agreed with the concept that overuse of antibiotics can eliminate protective flora and increase the opportunity for attachment of uropathogens as a preliminaty step to symptomatic UTI. Base on this argument we decided not to give antibiotic treatment to all cases with covert bacteriuria in our study. With this decision, six out of ten cases cured spontaneously, while four other cases, bacteria still persisted but all of them remain asymptomatic. Since antimicrobial treatment can substantially alter the bacterial flora associated with $\mathrm{ABU}$ and moreover such treatment may increase the risk of subsequent infection and scarring, most authors come to the conclusion that screening for asymptomatic bacteriuria in children should not be recommended as a part of routine well-child care. ${ }^{?}$ Although screening for bacteriuria in healthy children does not have a place in any age group, it is important to perform urine cultures freely in symptomatic children and especially in infants. ${ }^{10}$

\section{Acknowledgments}

The study was conducted as part of a pilot program held by Medical School University of Indonesia namely Community Health Program, sponsored and coordinated by Department of Clinical Pathology Cipto 
Mangunkusumo Gencral Hospital, and Japan Society for Promoting Sciences (JSPS). Thanks are due to Professor Sri Margono, MD from Department of Parasitology Medical School University of Indonesia for study coordination.

\section{References}

1. Savage DCL, Wilson M, Mc Hardy M, Dewar DAE, Fee WM. Covert bacteriuria of childhood. Arch Dis Child, 1973, 48:8-20.

2. Kunin CM, Zachra E, Paquin AJ. Urinary-tract infections in schoolchildren. 1. Prevalence of bacteriuria and associated urologic findings. New Eng J Med 1962; 266: $1287-96$

3. Kunin CM. A ten-year study of bacteriuria in schoolgirls: Final report of bacteriologic, urologic, and epidemiologic finding. J Infect Dis 1970, 122:382-93.

4. Newcastle Asymptomatic Bacteriuria Research Group. Asymptomatic bacteriuria in schoolchildren in Newcastle Upon Tyne. Arch Dis Child 1975, 50:90-102.

5. Savage DCL, HowieG, Adler K, Wilson ML Controlled trial of therapy in covert bacteriuria. Lancet 1975:358-61.

6. Newcastle Covert Bacteriuria Research Group. Covert bacteriutia in schoolgirls in Newcastle Upon Tyne: a 5-year follow up. Arch Dis Child 1981: 56:585-92.

7. Kemper K, Avner ED. The case against screening urinalyses for asymptomatic bacteriutia in children. Am J Dis Child, 1992, 146:343-6.

8. Meadow SR. Haematuria. In: Postlethwaite RJ (ed). Clinical Paediatric nephrology. 2nd ed. 1994; Butterworth Heinemann, Oxford. p. 1-14.

9. Merit D. How should girls with recurrent urinary tract infection and persistent vaginal discharge managed. Pediatric Ncphrol 1989;3:178.

10. Jodal U. Utinary tract infections: Significance, pathogenesis, clinical features and diagnosis. In: Postlcthwaite RJ (ed). Clinical paediatric nephrology. 2nd ed. Oxford: Butterworth - Heinemann; 1994. p. 151-9.

11. Hansson S, Jodal M, Noren L, Bjure J. In treated bacteriuria in asymptomatic girls with renal scarring. Pediatrics 1989;84:964-968.

12. Linshaw M. Asymptomatic bacteria and vesicoureteral reflux in children. Kidney Int 1996; 50:312-29. 